\title{
Investigation of the Physical Education and Sport Teacher Candidates' Attitudes towards Teaching Practice Course
}

\author{
Fatih Murathan ${ }^{1}$ \\ 'School of Physical Education and Sports, Adiyaman, Turkey \\ Email:fmurathan@gmail.com
}

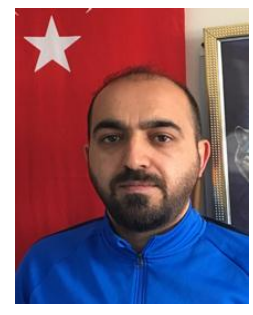

\begin{abstract}
It is known that the aims and achievements of the Higher Education Institution in the Teacher Education Guidelines of our country will enable the teacher candidates to develop a positive attitude from the professional point of view with the help of teaching practice course. In this context, Teaching practice course is a transformation of the theoretical knowledge acquired during the undergraduate course into practice. In the light of this information, it is aimed to examine and evaluate the professional attitudes of the last grade teacher candidates who are studying at the School of Physical Education and Sport in relation to the teaching practice course. A total of 128 female and 141 male candidate teachers who were educated in the 4th grade participated in the study as volunteers during the 2017-2018 academic year Spring semester in the Department of Physical Education and Sport Teaching. As a data collection tool " School Experience Lessons Scale of Attitude (ODDTÖ)" developed by Kılınç and Salman (2007) was used in the research. The Cronbach Alpha reliability co-efficient of scale is 0.94. As a result of the research, there was a statistically significant difference between the attitudes of the teacher candidates regarding the gender status, the university where they studied, and their attitudes towards teaching practice course. As a result, Teaching Practice courses are seen as very useful and important for teacher candidates. It can also be concluded that teaching practice is useful and necessary for professional experience by teacher candidates and this practice is seen as a necessary complementary factor to the profession.
\end{abstract}

Keywords: Physical education teacher candidate, Teaching practice, Attitude.

JEL Classification: 129 Education: Other

Citation | Fatih Murathan (2019). Investigation of the Physical Education and Sport Teacher Candidates' Attitudes towards Teaching Practice Course. Asian Journal of Education and Training, 5(1): 106-111.

History:

Received: 26 October 2018

Revised: 29 November 2018

Accepted: 4 January 2019

Published: 25 January 2019

Licensed: This work is licensed under a Creative Commons

Attribution 3.0 License $(\mathrm{oc})$ Ey

Publisher: Asian Online Journal Publishing Group
Funding: This study received no specific financial support.

Competing Interests: The author declares that there are no conflicts of interests regarding the publication of this paper.

Transparency: The author confirms that the manuscript is an honest, accurate, and transparent account of the study was reported; that no vital features of the study have been omitted; and that any discrepancies from the study as planned have been explained.

Ethical: This study follows all ethical practices during writing.

\section{Contents}

1. Introduction

2. Method

References. 


\section{Introduction}

One of the most important steps of the country rankings is their education applications. In this point of view, education is a platform where a significant amount of resource transfer materialized for increasing production, gaining respect and level of development of a country towards others. The main organizations, which provide most of the educational needs of people, are schools and their elements. Education of person, who will lead to the society, can only possible if the teachers are capable. Because of this all societies attach high importance to educational activities and the teachers are the focal point of these activities (Alakus et al., 2005).

Leader has emphasized, the importance of having knowledge at the information production stages of our time, in 2005. It is very clear that by the science and technology develops, a society needs schools which can improve the knowledge level and skills of the society more (McLaughlin and Talbert, 2006). This study presents the role of teacher on increasing the quality of education in schools. For example, Goodson and Hargreaves (2005) characterizes the teaching profession as one of the basic jobs by means of taking the responsibility of improving the human source which has been required by information society. Teaching profession and way and quality of educating teachers being questioned in many countries, and also it has been considered as one of the important problem areas of almost all education systems. For being successful at teaching profession which requires patience, sacrifice and continuous operation, one should work willingly and need to believe that he or she has the required theoretical information (Capa and Cil, 2000).

Educating teachers, is a comprehensive and multidimensional topic. Teacher education is a process which includes candidate selection, pre-service education, practice and evaluation of practice steps (Celikten et al., 2005). School Experience and Teaching Practice Course has been planned to provide a better training for teaching profession. This course aims to provide qualifications to teacher candidates to apply their liberal education, special field education, knowledge, skills and attitudes, which are about teaching profession, in a real education environment (Oyegm, 2008).

Teacher is one of the basic factors of education who has the most influence on generations while they are adopting to different life conditions and growing to be a successful citizen. Teacher is a person who is selfenhancing, transferring the knowledge in the best way, educating the students by considering the properties of culture and requirements of our time. A teacher is not only a person who is responsible from the transfer of knowledge but also a model for students by means of attitudes, emotional reactions and various habits (Zembat, 2014).

When the applications, which has been carried out to educate qualified teachers, have been taken into account in our country, many institutions have been created which aims to educate teachers and met the needs of our time (YÖK, 2007). However only Ministry of Education was responsible to educate teachers until 1982, related institutions and faculties in universities contributed to this mission (YÖK, 2007). In 1982 some of the teacher education institutions have been transferred to universities and some of them have lost their functions after the decision, which suggests to transfer the institutions to universities, of 10th National Education Congress in 23-26 June 1981 and the revision in the Higher Education Law (Law No: 2547). After this decision the universities have been responsible to educate qualified teachers (YÖK, 2007). The teacher educating faculties and institutions have focused on liberal education, pedagogical formation and specific field courses and the curriculum has been updated several times until today.

The main targets of the Teacher Education Guidelines of Higher Education Institution (YÖK) are increasing the professional knowledge level of teacher candidate, teaching how to learn together and how to teach (Sisman, 2000). According to these main targets the period of educating qualified teachers includes various levels. Field selection process of candidate, undergraduate education, internship in selected practice schools and evaluation of internship process are these levels (Kavcar, 2002). There are very important and mostly theoretical courses (Introduction to Educational Science, Education Psychology, Assessment and Evaluation, Special Teaching Methods, Principle, Methods and Techniques of Education) and also practical courses (School Experience and Teaching Practice) in the curriculum.

To detect that which mechanisms or processes are effective on the academic success of students is very important for a teacher by means of teaching profession (Caprara et al., 2006). But there are many variables which effect the goal orientation and level of educational effort of teachers. For example, some scientists (Rimm-Kaufman and Sawyer, 2004) reported that priorities and attitudes of teachers closely related with their classroom applications and behaviors. Because attitudes effect not only social perceptions but also behaviors (Kağıtçıbaşı, $2010)$.

Attitude, which is an important precursor, has been characterized as a psychological variable which has been considered as an important analyzer of behavior by means of cognition, emotionality and behaviorism. Attitude includes a tendency, againstness or a favor to an attitude object (Cakır et al., 2006).

The professional attitude (positive or negative) of teacher candidate is an outstanding factor which directly effects the education of teachers and generations because it is an acquired, developing and changeable element like all composed objects in organism (Can, 1987). The teacher education organizations aim to provide more effective behaviors in professional life by bringing knowledge, emotions and skills to students. One of the conditions for teacher candidates to apply the teacher profession better is having positive attitudes towards the profession. It is essential to detect and transform the attitudes of teacher candidates towards teaching profession to positive if it is negative (Semerci and Semerci, 2004). Additionally, teacher educating applications and working conditions of teachers change frequently. Because of this, it is very important to make actual studies to detect the attitudes of teacher candidates towards teaching profession (Üstüner, 2006).

When it has been considered the fact that attitudes form a basis for thoughts and behaviors, the necessity for the individual to develop a positive attitude in being oriented to success draws the attention (Çepni et al., 2006).

It has been concluded that the knowledge, skills and attitudes which exist in teacher education courses, can be applied in professional field by teaching practice courses. Teaching practice is an important activity where the theoretical knowledge transforms to practice. Teacher candidates should be familiar with professional field before they start to work (Küçükahmet, 1993; Gökalp, 2007). The target of these practical courses is to provide experience 
to teacher candidates in professional field (Harmandar et al., 2000). Alakus et al. (2005) have been concluded that school experience and teaching practice contribute to teacher candidate in several ways as follows; support the teacher candidates' decisions and actions about profession, develop preparations for profession, help candidates to prepare themselves for professional development activities while gaining experience, help to learn law, regulations and instructions of profession, gain technical and theoretical skills about field, improving, responsibility and judgement (Alakus et al., 2005).

The applications, for educating qualified teachers, are an old problem which have been discussed and theoretically transformed in educational history of our country. The discussions were focused on the applicability and compatibility of the education programs with the reality of our country (Yüksel, 2011). Some of the very important studies were evaluated which are about the education of teachers and increasing the quality of educated teachers (Santoro, 1997; Oğuz, 2004; Elmore, 2007; Kabakci et al., 2009). After the efforts on educating qualified teachers for a long time in Turkey, YÖK and World Bank collaborated for a project named "The National Education Developing Project" to increase the quality of teacher education in 1994. It has been discussed in this project that how a better teacher profile can be created. At the end of the discussions, it has been concluded that the Turkish teachers are capable by means of theoretically but there is a lack at the practical skills (Harmandar et al., 2000).

The investigation of attitudes of teacher candidates towards the profession and evaluation of attitudes by means of various variables were aimed in this study.

\section{Method}

\subsection{Population and Sample}

The population consists of students who are at the last year of Physical Education and Sports Education Course of universities. 128 female and 141 male students, who are at the last year of their education at the 20172018 education semesters, have attended to the study as volunteer from 5 different universities which have similar student number. The average of the ages of samples was detected as 22.12 1.02 .

\subsection{Data Collecting Tools}

"School Experience Lessons Scale of Attitude", which has been generated by Kılınç and Salman (2007) has been used to collect data. The Cronbach Alpha reliability co-efficient of scale is 0.94 . The scale includes totally 20 items (14 positive and 6 negative). Minimum score is 20 and maximum score is 100 for this scale which has been prepared as 5-point Likert Scale type. So, if the total score of a sample would be divided to item number, the average score of a sample can be obtained which may provide information about the attitudes of related sample towards school practice course. If sample gets more than 3, it means a positive attitude and if the score is below 3 it means a negative attitude. ( $5=$ Totally agree, $1=$ Totally disagree) (Kılınç and Salman, 2007).

Table-1. Item-test correlations, factor burdens and score averages of Attitude Scale Items towards School Experience and Teaching practice Lesson

\begin{tabular}{l|l|l|l}
\hline Item No & Item-Test Correlation & Factor Burden Value & Average \\
\hline 1. & 0.53 & 0.43 & 4.16 \\
\hline 2. & 0.59 & 0.35 & 3.22 \\
\hline 3. & 0.72 & 0.58 & 3.41 \\
\hline 4. & 0.58 & 0.44 & 3.47 \\
\hline 5. & 0.62 & 0.46 & 4.1 \\
\hline 6. & 0.64 & 0.65 & 3.7 \\
\hline 7. & 0.57 & 0.32 & 3.53 \\
\hline 8. & 0.69 & 0.64 & 3.22 \\
\hline 9. & 0.69 & 0.52 & 3.51 \\
\hline 10. & 0.78 & 0.65 & 3.22 \\
\hline 11. & 0.69 & 0.46 & 3.26 \\
\hline 12. & 0.71 & 0.68 & 3.71 \\
\hline 13. & 0.75 & 0.69 & 3.59 \\
\hline 14. & 0.65 & 0.72 & 3.92 \\
\hline 15. & 0.59 & 0.62 & 3.74 \\
\hline 16. & 0.71 & 0.62 & 3.50 \\
\hline 17. & 0.64 & 0.67 & 3.22 \\
\hline 18. & 0.46 & 0.53 & 4.39 \\
\hline 19. & 0.63 & 0.73 & 4.00 \\
\hline 20. & 0.66 & 0.51 & 3.26 \\
\hline
\end{tabular}

Source: Kılınç and Salman (2007)

\subsection{Statistical Analysis}

SPSS (Statistical Packet for Social Sciences) 22.00 software was used for statistical analysis of data which calculated by two level scale form, which created at the variable dependence stage. Descriptive statistical methods, frequency $(\mathrm{f})$, percentage $(\%)$ and arithmetic average $(\mathrm{x})$, have been applied on the data and $\mathrm{t}$-Test and ANOVA tests were used to detect the differences between the dependent variables. Levene test has been used to detect that which groups have the difference, which has been calculated by ANOVA tests.

\section{Results}

Inclusive statistical evaluations have been reported in this section within the scope of the aim and the methodology. Accordingly; 


\begin{tabular}{|c|c|c|c|}
\hline \multicolumn{2}{|l|}{ Variable Gender } & \multirow{2}{*}{$\frac{\mathbf{N}(\mathbf{2 6 9})}{128}$} & \multirow{2}{*}{$\frac{\%}{47.58}$} \\
\hline & Female & & \\
\hline & Male & 141 & 52.42 \\
\hline \multirow{3}{*}{ General academic score average } & 2.00 and lower & 73 & 27.13 \\
\hline & Between 2.01-3.00 & 144 & 53.53 \\
\hline & 3.01 and higher & 52 & 19.34 \\
\hline \multirow{3}{*}{ Monthly income level } & $750 \mathrm{TL}$ and lower & 105 & 39.03 \\
\hline & $751 \mathrm{TL}-1500 \mathrm{TL}$ & 118 & 43.86 \\
\hline & $1501 \mathrm{TL}$ and higher & 46 & 17.10 \\
\hline \multirow{3}{*}{ Mostly lived in } & Village/Town & 61 & 22.69 \\
\hline & District center & 72 & 26.76 \\
\hline & City/Metropolitan & 136 & 50.55 \\
\hline \multirow{5}{*}{ University } & A & 59 & 21.93 \\
\hline & $\mathrm{B}$ & 61 & 22.67 \\
\hline & $\mathrm{C}$ & 55 & 20.44 \\
\hline & $\mathrm{D}$ & 52 & 19.33 \\
\hline & $\mathrm{E}$ & 42 & 15.62 \\
\hline
\end{tabular}

Descriptive statistics of samples were reported on Table 2. According to this, it has been calculated that the $47.58 \%$ of samples are female and $52.42 \%$ of samples are male. And academic score average of $27.13 \%$ of samples is $\leq 2.00,53.53 \%$ of samples between is $2.01-3.00$ and $19.34 \%$ of samples is $\geq 3.01$.

The university variable has been encoded as A, B, C, D, E on Table 2.

Table-3. Test Results of Attitude Scale Towards Teaching Practice Lesson for Teacher Candidates by Means of Gender

\begin{tabular}{l|l|l|l|l|l|l}
\hline & Gender & N & $\mathbf{x}$ & Sd. & F & p \\
\hline \multirow{2}{*}{$\begin{array}{l}\text { TEACHING PRACTICE } \\
\text { ATTITUDE SCALE }\end{array}$} & Male & 141 & 3.18 & 0.66 & \multirow{2}{*}{1.33} & \multirow{2}{*}{$\mathbf{0 . 0 0 ^ { * }}$} \\
\cline { 2 - 6 } & Female & 128 & 3.86 & 0.87 & & \\
\hline
\end{tabular}

* $\mathrm{p}<0.05$

As it can be seen from Table 3, the average score for female attitudes is $3.86 \pm 087$ and 3.18 \pm 0.66 for males. A statistically significant difference has been detected between the attitude score of males and females $(p>0.05)$. According to obtained results the attitude score of females are higher than the males.

Table-4. The Anova Test Results of General Academic Score Average and Attitude Scale Average Towards Teaching practice Lesson for Teacher Candidates

\begin{tabular}{|c|c|c|c|c|c|c|}
\hline & Variance Source & $\begin{array}{l}\text { Sum of } \\
\text { Squares }\end{array}$ & D & $\begin{array}{l}\text { Average of } \\
\text { Squares }\end{array}$ & $\mathbf{F}$ & $\mathbf{p}$ \\
\hline \multirow[t]{3}{*}{$\begin{array}{l}\text { TEACHING PRACTISE ATTITUDE } \\
\text { SCALE }\end{array}$} & Between groups & 24.544 & 4 & 11.601 & \multirow[t]{3}{*}{.86} & \multirow[t]{3}{*}{$.002^{*}$} \\
\hline & In group & 3955.327 & 265 & 2451.1878 & & \\
\hline & Total & 3979.871 & 269 & & & \\
\hline
\end{tabular}

* $\mathrm{p}<0.05$

According to the results on Table 4 a statistically significant difference has been detected between the average of academic scores and attitude scores towards teaching practice. According to the obtained results, the scores of students who have average academic score $\leq 2.00$ are lower than students who have average academic score $\geq 3.00$. According to the results of ÖUTÖ Levente test, which has been carried out to detect which groups are the source of difference, a relation direction has been detected between the students who have average academic score below 2.00 and over 3.00 .

\begin{tabular}{|c|c|c|c|c|c|c|}
\hline & University & $\mathbf{N}$ & $\overline{x^{-}}$ & Sd. & $\mathbf{F}$ & $\bar{p}$ \\
\hline \multirow[t]{5}{*}{ TEACHING PRACTISE ATTITUDE SCALE } & $\mathrm{A}$ & 59 & 3.49 & 0.28 & \multirow[b]{5}{*}{2.6254} & \multirow[b]{5}{*}{$0.04^{*}$} \\
\hline & $\mathrm{B}$ & 61 & 2.88 & 0.69 & & \\
\hline & $\mathrm{C}$ & 55 & 3.02 & 1.12 & & \\
\hline & $\mathrm{D}$ & 52 & 3.28 & 0.80 & & \\
\hline & $\mathrm{E}$ & 42 & 3.78 & 1.49 & & \\
\hline
\end{tabular}

* $\mathrm{p}<0.05$

Statistically significant differences detected between the universities and teaching practice attitude scale score average of teacher candidates (Table 5). It can be concluded that different social and economic standards of cities where the universities are located, different educational policies may be reasons for this difference.

\section{Discussion}

The attitudes of physical education teacher candidates, towards teaching practice course, have been evaluated by means of different variables in this study. Obtained results by attitude scale can be summarized as;

The number of female candidates is 128 and their average attitude score is $3.86+0.87$, number of male candidates is 141 and their average attitude score is $3.18+0.66$. A statistically significant difference has been obtained between the average attitude scores of male and females $(\mathrm{p}<0,05)$. According to this result the attitudes of female teacher candidates are higher that the male teacher candidates. In a related field study, the attitudes of 
primary school teacher candidates have been evaluated by interview and no significant difference obtained by means of student opinions (Riza and Hamurcu, 2000). Aydın et al. (2007) reported in 2007 that, students determined that the School Experience Course is useful and teaching practice contributed to the learning period a lot. Therefore, the results which have been obtained from our study by gender variable are not in harmony with literature. But the results are compatible with the study of Aydın et al. (2007) which determines the teaching practice as useful.

It has been concluded that the teacher candidates should spend more time in practice schools and this is one of the sub problems of the field (Hawley, 1993). The courses, which the candidates can practice, are activities that the candidates can contact with student one to one, transfers the experience, organize new development exercises and find educationally productive areas. It has also been concluded that to give more time to candidates in practice schools is not recommended by means of learning strategy and professional attitude. As a result, when the effect of these experiences to the future professional life of candidates considered, to provide chance to the teacher candidates in practice schools to develop their professional experience matters.

It has been evaluated that the attitudes of teacher candidates towards teaching practice course depends of the university variable and there is a significant relation between this difference and teaching practice attitude scale score average. According to statistical test of this data, the teacher candidates of university $\mathrm{E}$ have the highest average score $(\mathrm{x}=3.78)$ between the attitude scale and university variable. And the lowest average belongs to $(\bar{x}=2,88$ university $\mathrm{B}$. The results of this study about the university variable are compatible with literature. The reasons for why university matters can be summarized as; unsatisfying number of practice schools, lack of sport facilities, lack or weakness of branch teachers on field. It can be concluded that these factors are important on the status of attitudes of teacher candidates towards teaching practice.

Average age of samples is 22.12 1 1.02. Most of the volunteers (37\%) are between 22-23. Results have stated that there is not any meaningful relation between the ages and the attitudes of teacher candidates. A similar result has been reported by Murathan and Özdemir (2017).

When the last words of teacher candidates, which has been added to the end of the survey if they want to add anything, examined, it has been evaluated that there is a lack of communication between the supervisor in practice school and responsible academician at university. This result is compatible with the reports of Gökçe and Demirhan (2005) which has been carried out in 80 public schools with 341 teacher candidates. It has been concluded in reports which are the structure of the problem that teacher candidates want to meet with wise, positively attituded and sympathetic supervisors in practice schools (Leask, 1995; Adey, 1997; Maynard, 2000; Zanting et al., 2001; Azar, 2003).

\section{Conclusion}

It has been evaluated that the teacher candidates have positive attitudes scores towards teaching practice course and they think that these practical courses are useful. Therefore, it can be concluded that to increase the number of courses, which are similar to teaching practice course, in curriculum is essential.

According to the obtained results the attitudes of teacher candidates are positive but the instructions and guides of universities which are prepared for teaching practice and internship are not easily understandable. Candidates were not informed enough about paperwork stages of teaching practice and because of this they slog on writing the final results.

According to the results of the study the suggestions can be summarized as;

- The studies on attitude can be evaluated by applying to large populations.

- The effects of different variables can be considered towards attitudes on teaching practice.

- New investigations, which are oriented for teaching practice partners (student, teacher, school managers, academicians), can be planned to contribute to the solution of problems.

New studies, which evaluate the efficiency of investigation by considering the socioeconomic environment and structure of society, can be carried out.

\section{References}

Adey, W.R., 1997. Bioeffects of mobile communications fields: Possible mechanisms for cumulative dose. In mobile communications safety. Boston, MA: Springer. pp: 95-131.

Alakus, A.O., B. Oral and L. Mercin, 2005. Perceptions of prospective teachers in school of fine arts education - II. National Education Journal, 168.

Aydın, S., A. Selçuk and M. Yeșilyurt, 2007. The effect of "school experience II" on pre-service elementary teachers (Yuzuncu Yil Unıversıty Sample. Yüzüncü Yıl University, Education Faculty Journal, 4(II): 75-90.

Azar, A., 2003. Reflections of views on school experience and teaching practice courses. National Education Journal, 159(04.04): 18.

Cakır, Ö., A. Kan and Ö. Sünbül, 2006. Evaluation of teaching profession and non-thesis master programs in terms of attitude and selfefficacy. Mersin University Faculty of Education Journal, 2(1): 36-47.

Can, G., 1987. Evaluation of the attitudes of teacher candidates' towards teaching certificate courses and their learning modalities. Anadolu University Education Faculty Journal, 1(2): 159-170.

Capa, Y. and N. Cil, 2000. Investigation of teacher candidates' attitudes towards teaching profession from different variables. Journal of Hacettepe University Faculty of Education, 18(18): 123.

Caprara, G.V., C. Barbaranelli, P. Steca and P.S. Malone, 2006. Teachers' self-efficacy beliefs as determinants of job satisfaction and students' academic achievement: A study at the school level. Journal of School Psychology, 44(6): 473-490. Available at: https://doi.org/10.1016/j.jsp.2006.09.001.

Celikten, M., M. Sanal and Y. Yeni, 2005. Teaching profession and features. Erciyes University Journal of the Institute of Social Sciences, 19(2): 207-237.

Çepni, S., Ö. Çakır, A. Kan and Ö. Sünbül, 2006. Evaluation of teaching profession and non-thesis master programs in terms of attitude and self-efficacy. Mersin University Education Faculty Journal, 2(1): 36-47.

Elmore, R.F., 2007. School reform from the inside out: Policy, practice, and performance. Cambridge, MA: Harvard Education Press.

Gökalp, M., 2007. Levels of School Students' Perception of School Experience in. University. D. Ziya Gökalp Faculty of Education Journal, 9: 56-63.

Gökçe, E. and C. Demirhan, 2005. Teacher candidates and supervising teachers' opinions about activities of teaching practice in elementary schools. Ankara University, Journal of Educational Sciences, 1: 43-71. 
Goodson, I. and A. Hargreaves, 2005. Series editors' preface. In A. Harris ve D.Muijs. Improving schools through teacher leadership. New York: Open University Press. pp: 7-10.

Harmandar, M., S. Bayrakçeken, R.Y. Kıncal, E. Büyükkasap and S. Kızılkaya, 2000. Application of school experience and evaluation of results in the faculty of education of Kâzım Karabekir. National Education Journal, 148: 3-6.

Hawley, F., 1993. The moral and conceptual universe of cockfighters: Symbolism and rationalization. Society \& Animals, 1(2): 159-168. Available at: https://doi.org/10.1163/156853093x00055.

Kabakci, I., A. Kurt and G. Becit, 2009. Viewpoints of pre-service computer teachers on the advantageous of school practicum courses. Anadolu University Journal of Social Sciences, 9(1): 169-184.

Kağıtçıbaşı, Ç., 2010. People and people today: Introduction to social psychology. 12th Edn., Istanbul: Evrim Publishing House.

Kavcar, C., 2002. Branch teacher training in the republic period. Ankara University Faculty of Educational Sciences Journal, 35(1-2): 1-14.

Kılınç, A. and S. Salman, 2007. Developing attitude scale for school experience courses. Gazi Education Faculty Journal, 27(1): 23-35.

Küçükahmet, L., 1993. Teacher training programs and applications. Ankara: Gazi University Faculty of Communication. Press.

Leask, M., 1995. Towards a pedagogical framework for the use of multimedia and new technologies associated with the information superhighway. Paper Presented at the British Educational Research Association Conference, Bath, 14-17 September.

Maynard, T., 2000. Learning to teach or learning to manage mentors? Experiences of school-based teacher training. Mentoring and Tutoring, 8(1): 17-30. Available at: https://doi.org/10.1080/713685510.

McLaughlin, M.W. and J.E. Talbert, 2006. Building school-based teacher learning communities: Professional strategies to improve student achievement. New York: Teachers College Press.

Murathan, T. and K. Özdemir, 2017. Investigation of the attitudes of physical education teacher candidates toward teaching profession and sense of competence in terms of some variables. Journal of Education and Learning, 6(4): 229-238. Available at: https://doi.org/10.5539/jel.v6n4p229.

Oğuz, A., 2004. The effects of school experience I on teacher candidates. Dumlupinar University Journal of Social Sciences, 1 1: 141-162.

Oyegm, 2008. General directorate of teacher training and education. Special field competences of science and technology teachers. Ankara: Ministry of National Education.

Rimm-Kaufman, S.E. and B.E. Sawyer, 2004. Primary-grade teachers' self-efficacy beliefs, attitudes toward teaching, and discipline and teaching practice priorities in relation to the" responsive classroom" approach. The Elementary School Journal, 104(4): $321-341$. Available at: https://doi.org/10.1086/499756.

Riza, E.R. and H. Hamurcu, 2000. School experience of primary school students and their views on teaching practice. Pamukkale University Faculty of Education Journal, 8(Special Issue): 1-8.

Santoro, N., 1997. The construction of teacher identity: An analysis of school practicum discourse. Asia-Pacific Journal of Teacher Education, 25(1): 91-99. Available at: https://doi.org/10.1080/1359866970250108.

Semerci, N. and Ç. Semerci, 2004. Teacher attitudes in Turkey. Fırat University Journal of Social Sciences, 14(1): 137-146.

Sisman, M., 2000. Introduction to educational science. Pegem Academy.

Üstüner, M., 2006. Validity and reliability study of attitude scale for teaching profession. Educational Administration in Theory and Practice, $12(45): 109,127$.

YÖK, 2007. Faculties of teacher education and education (1982-2007). Available from http://www.yok.gov.tr/documents/10279/49665/yok_ogretmen_kitabi_Accessed 10.1 1.2018].

Yüksel, S., 2011. Education faculties and teacher training in Turkish universities. 2nd Edn., Ankara: Pegem Academy.

Zanting, A., N. Verloop and J.D. Vermunt, 2001. Student teachers' beliefs about mentoring and learning to teach during teaching practice. British Journal of Educational Psychology, 71(1): 57-80. Available at: https://doi.org/10.1348/000709901158398.

Zembat, R., 2014. Teacher in education system. (Ed. A. Oktay), Introduction to education science. 7th Edn., Ankara: Pegem Academy. 